RESIDENT

\& FELLOW

SECTION

Section Editor

Mitchell S.V. Elkind, MD, MS

G. Tsivgoulis, MD, FESO

I. Heliopoulos, MD

K. Vadikolias, MD

A. Patousi, MD

A. Giatromanolaki, MD

E. Sivridis, MD

C. Piperidou, MD

Address correspondence and reprint requests to Dr. Georgios Tsivgoulis, Kapodistriou 3, Nea Xili, Alexandroupolis, Greece 68100

tsivgoulisgiorg@yahoo.gr

\title{
Teaching NeuroImages: \\ Ultrasound findings in giant-cell arteritis
}

Figure Sonography
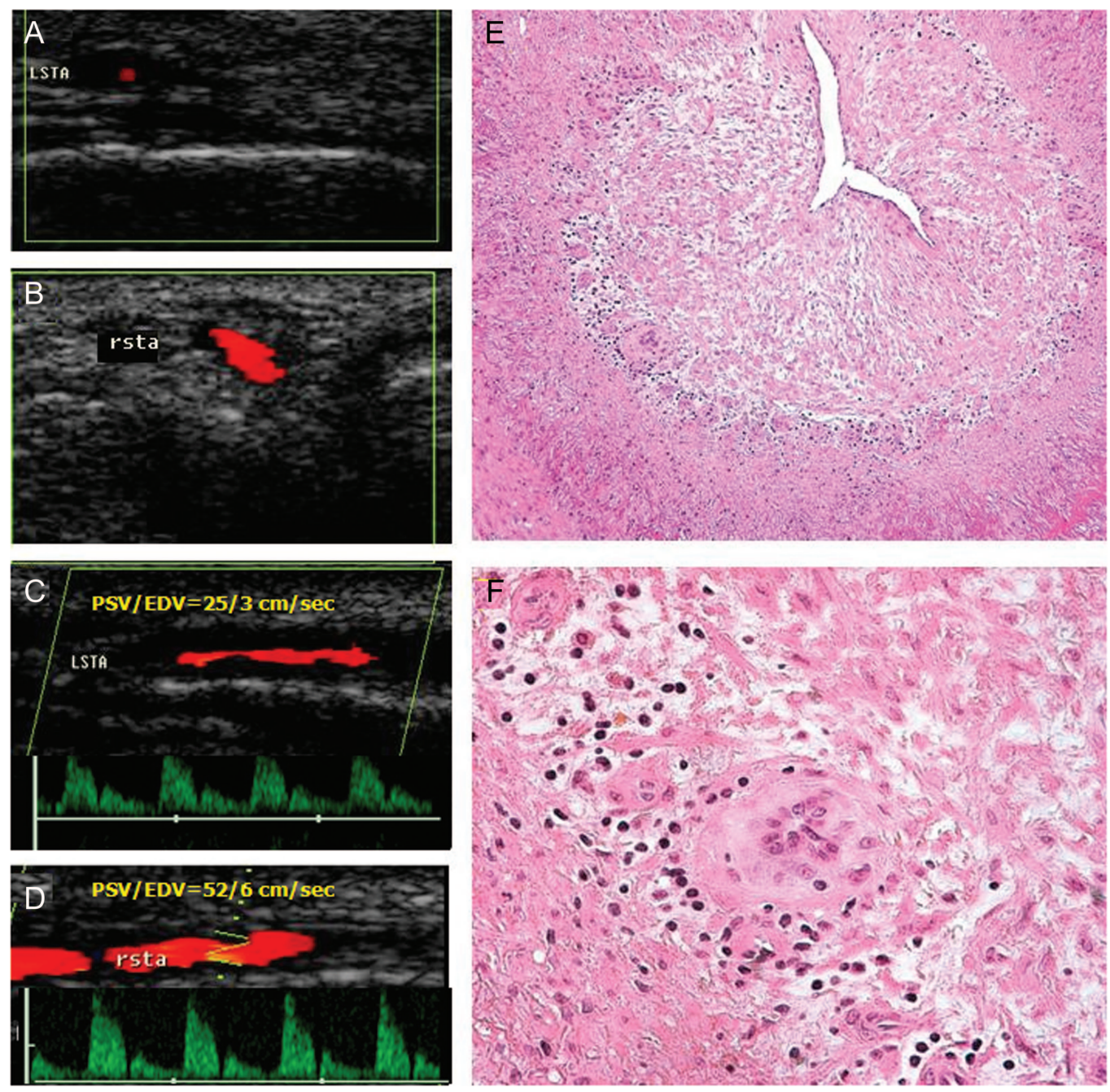

Extracranial duplex of left superficial temporal artery (STA) showing reduced color-filling and vessel-wall thickening in form of a dark halo in axial (A) and longitudinal (C) plane. Note the normal color-filling in right STA in axial (B) and longitudinal (D) plane. Blood flow velocity spectra have been included as inserts in C and D. Left STA biopsy $(\times 100)$ showing inflammatory infiltrates involving the entire vessel wall, marked intimal thickening, and fragmentation of the internal elastic lamina (E). Presence of giant cells is shown at a higher magnification $(\times 400)(F)$.

A 67-year-old man presented with a throbbing left temporal headache of worsening intensity over 10 days without visual disturbance. Physical examina- tion disclosed left temporal scalp tenderness and a decreased temporal artery pulse. Neurologic and funduscopic examinations had normal results. Erythro-

From the Departments of Neurology (G.T., I.H., K.V., A.P., C.P.) and Pathology (A.G., E.S.), Democritus University of Thrace, University Hospital of Alexandroupolis, Alexandroupolis, Greece.

Disclosure: The authors report no disclosures. 
cyte sedimentation rate was $3 \mathrm{~mm} /$ hour, and the C-reactive protein $1.5 \mathrm{mg} / \mathrm{dL}$. Emergent duplex ultrasound disclosed a hypoechoic circumferential thickening (halo sign) around the left superficial temporal artery (STA) lumen (figure, A and C), indicating wall edema. The patient was immediately started on corticosteroids with complete resolution of his symptoms. STA biopsy confirmed giant-cell arteritis (GCA) (figure, E and F).

Ultrasound may contribute to GCA diagnosis by visualizing characteristic findings in the STA wall. ${ }^{1} \mathrm{~A}$ recent meta-analysis reported that the unilateral halo sign achieved an overall sensitivity of $68 \%$ and specificity of $91 \%$ in biopsy-proven GCA. ${ }^{2}$

\section{REFERENCES}

1. Schmidt WA, Kraft HE, Vorpahl K, et al. Color duplex ultrasonography in the diagnosis of temporal arteritis. N Engl J Med 1997;337:1336-1342.

2. Arida A, Kyprianou M, Kanakis M, Sfikakis PP. The diagnostic value of ultrasonography-derived edema of the temporal artery wall in giant cell arteritis: a second meta-analysis. BMC Musculoskelet Disord 2010;11:44. 


\section{Neurology}

\section{Teaching NeuroImages: Ultrasound findings in giant-cell arteritis}

G. Tsivgoulis, I. Heliopoulos, K. Vadikolias, et al.

Neurology 2010;75;e67-e68

DOI 10.1212/WNL.0b013e3181f881e9

This information is current as of October 18, 2010

\section{Updated Information \&} Services

References

Subspecialty Collections

Permissions \& Licensing

Reprints including high resolution figures, can be found at: http://n.neurology.org/content/75/16/e67.full

This article cites 2 articles, 0 of which you can access for free at: http://n.neurology.org/content/75/16/e67.full\#ref-list-1

This article, along with others on similar topics, appears in the following collection(s):

Infarction

http://n.neurology.org/cgi/collection/infarction Ultrasound

http://n.neurology.org/cgi/collection/ultrasound

Information about reproducing this article in parts (figures,tables) or in its entirety can be found online at:

http://www.neurology.org/about/about_the_journal\#permissions

Information about ordering reprints can be found online:

http://n.neurology.org/subscribers/advertise

Neurology ${ }^{\circledR}$ is the official journal of the American Academy of Neurology. Published continuously since 1951, it is now a weekly with 48 issues per year. Copyright Copyright $@ 2010$ by AAN Enterprises, Inc.. All rights reserved. Print ISSN: 0028-3878. Online ISSN: 1526-632X.

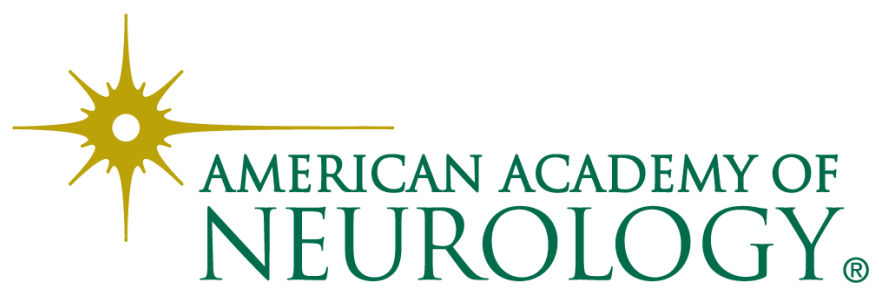

